$\begin{array}{rr}\text { JURNAL } & \text { Volume } 11, \text { Nomor } 1, \text { Februari } 2015 \\ \text { FIT(1)PATOLOGI } & \text { Halaman } 23-28 \\ \text { I N D O N E S I } & \text { DOI: } 10.14692 / \text { jfi.13.1.23 } \\ \text { ISSN: } 0215-7950 & \end{array}$

\title{
Fusarium Nonpatogen sebagai Agens Hayati Penyakit Rebah Kecambah pada Tanaman Terung
}

\author{
Nonpathogenic Fusarium as Biocontrol Agent \\ for Damping-Off Disease of Eggplant
}

\author{
Ahmad Muslim* \\ Universitas Sriwijaya, Ogan Ilir 30662
}

\begin{abstract}
ABSTRAK
Rhizoctonia solani merupakan patogen tular tanah yang sangat penting yang dapat menyebabkan rebah kecambah, busuk batang, dan busuk akar. Penelitian ini bertujuan menentukan kemampuan isolat Fusarium nonpatogen yang diaplikasikan pada awal pembibitan dalam mengendalikan penyakit rebah kecambah yang disebabkan $R$. solani pada tanaman terung. Perlakuan Fusarium nonpatogen memberikan pengaruh nyata dan sangat efektif dalam menghambat keparahan penyakit rebah kecambah dengan persentase penekanan keparahan penyakit berkisar antara 59.02 dan 96.72\%. Perlakuan Fusarium nonpatogen pada pembibitan juga mampu meningkatkan tinggi bibit dan bobot basah berturut-turut berkisar 40.00-60.98\%, dan 21.80-66.53\%. Hasil penelitian menunjukkan bahwa Fusarium nonpatogen merupakan agens pengendalian biologi yang potensial untuk menanggulangi penyakit rebah kecambah yang disebabkan $R$. solani.
\end{abstract}

Kata kunci : keparahan penyakit, patogen tular tanah, pengendalian biologi

\begin{abstract}
Rhizoctonia solani is an important soil borne pathogen causing damping-off, stem and root rot disease. The pathogen has a wide range of hosts including eggplant. This experiment was conducted to determine the ability of nonpathogenic isolates of Fusarium against rhizoctonia damping-off caused by $R$. solani in eggplant by seedling treatment. The result showed that treatment with nonpathogenic Fusarium significantly inhibited damping-off disease development. Nonpathogenic Fusarium effectively reduced disease severity, ranged from 59.02-96.72\%. Treatment with nonpathogenic Fusarium was also able to increase plant height and fresh weight of eggplant seedling ranged from $40.00-60.98 \%$ and $21.80-66.53 \%$, respectively. This results indicated that nonpathogenic Fusarium could be applied as potential biocontrol agent for damping-off disease caused by $R$. solani.
\end{abstract}

Key words : biological control, disease severity, soil borne pathogen

\section{PENDAHULUAN}

Tanaman terung (Solanum melongena L.) merupakan tanaman sayuran yang sangat penting yang tumbuh dan dibudidayakan di seluruh dunia, baik di daerah tropis maupun subtropis. Cina merupakan negara penghasil terungtertinggidiAsia, diikutioleh India, Mesir, Turki, Jepang dan Italia (Daunay dan Janick 2007). Produksi terung di Indonesia tahun 2012 sebesar 518827 ton dan meningkat pada tahun 2013 menjadi 545646 ton (BPS 2014).

\footnotetext{
*Alamat penulis korespondensi: Jurusan Hama dan Penyakit Tumbuhan, Fakultas Pertanian, Universitas Sriwijaya, Jalan Raya Palembang-Prabumulih, KM 32, Indralaya, Ogan Ilir, 30662.

Tel: 0711-580663, Faks:0711-580059. Surel: Limpal2003@yahoo.com
} 
Rhizoctonia solani merupakan penyakit tular tanah yang sangat penting dan mempunyai kisaran inang yang luas mulai dari famili Papilionaceae, Solanaceae, Cruciferae, Cucurbitaceae, dan berbagai jenis tanaman sayuran lainnya. Patogen ini dapat menyebabkan berbagai macam gejala, mulai dari rebah kecambah, busuk batang, busuk akar, busuk hipokotil, hawar daun, sampai kanker akar (Chin et al. 1996). Sejauh ini pengendalian penyakit rebah kecambah biasa dilakukan petani dengan penyemprotan pestisida, sementara efek residu penggunaan pestisida di tanaman, tanah, dan air menjadi isu kesehatan dan lingkungan yang sangat penting. $\mathrm{Lu}$ (2011) melaporkan bahwa tanaman terung yang diproduksi oleh masyarakat di Filipina mengandung residu pestisida cypermethrin and chlorpyrifos yang mengkhawatirkan. Pengendalian biologi dengan memanfaatkan mikroorganisme antagonis merupakan alternatif pengendalian yang paling tepat untuk mendukung pengendalian penyakit terpadu dan berkelanjutan.

Fusarium nonpatogen merupakan agens hayati yang potensial untuk mengendalikan penyakit layu fusarium pada tanaman tomat dan semangka, serta layu verticillium pada tanaman terung (Yamaguchi et al. 1992; Larkin et al. 1996). Pemanfaatan Fusarium nonpatogen untuk mengendalikan penyakit rebah kecambah pada tanaman terung belum banyak dilaporkan. Oleh karena itu, penelitian bertujuan menentukan kemampuan isolat Fusarium nonpatogen untuk mengendalikan penyakit rebah kecambah yang disebabkan oleh $R$. solani melalui aplikasi di pembibitan.

\section{BAHAN DAN METODE}

\section{Inokulum Fusarium dan $R$. solani}

Inokulum Fusarium yang digunakan dalam penelitian ini, diisolasi dari tanah rizosfer lahan rawa lebak di Kabupaten Ogan Ilir, Sumatera Selatan yang sudah diuji kemampuannya sebagai cendawan pemacu pertumbuhan tanaman dan sudah dievaluasi tidak menimbulkan penyakit pada tanaman (Muslim et al. 2006). Isolat $R$. solani diisolasi dari akar tanaman cabai yang ditanam di lahan rawa lebak yang menunjukkan gejala penyakit rebah kecambah. Masing-masing cendawan Fusarium dan $R$. solani disiapkan dalam bentuk inokulum menggunakan substrat campuran $40 \mathrm{~g}$ dedak, $30 \mathrm{~g}$ bungkil jagung, dan $10 \mathrm{~g}$ merang padi.

Masing-masing isolat ditumbuhkan pada medium agar-agar dekstrosa kentang (ADK) selama 3 hari pada suhu ruangan. Sebanyak 5-7 potongan miselium $(5 \mathrm{~mm})$ dari masing-masing biakan dipotong dari ujung pertumbuhan hifa, selanjutnya diletakkan ke dalam erlenmeyer yang sudah berisi medium biakan yang terdiri atas campuran dedak, jagung, merang padi basah (dicampur air suling dengan perbandingan 1:0.8 b/v campuran dedak, jagung, dan merang padi kering:air suling) yang sudah disterilkan dengan autoklaf di dalam erlemneyer (500 $\mathrm{mL}$ ). Masing-masing biakan diinkubasi selama 10-14 hari pada suhu ruangan. Biakan digoyang setiap hari supaya kolonisasi cendawan pada subsrat merata, kemudian substrat yang terkolonisasi oleh masingmasing cendawan dikeringanginkan selama 7 hari dan disimpan pada suhu $4{ }^{\circ} \mathrm{C}$ sebelum digunakan (Muslim et al. 2003).

\section{Uji Kemampuan Fusarium Nonpatogen dalam Menekan Penyakit Rebah Kecambah}

Medium tanam yang digunakan ialah tanah yang telah dibersihkan dan diayak sehingga didapatkan butiran-butiran tanah halus, dicampur pasir dan pupuk kandang dengan perbandingan 2: 1: 1. Perlakuan bibit tanaman terung dengan Fusarium dilakukan dengan cara mensterilkan benih terung menggunakan alkohol 70\%, kemudian ditumbuhkan dalam pot kecil dengan diameter $2.7 \mathrm{~cm}$ dan tinggi $3 \mathrm{~cm}$ yang telah diisi dengan campuran tanah, pasir dan pupuk kandang yang telah diinokulasi Fusarium nonpatogen dengan konsentrasi 2\% (b/b). Benih terung dibiarkan tumbuh selama 10 hari, selanjutnya tanaman beserta tanahnya dipindahkan ke pot yang berukuran lebih besar dengan diameter $7 \mathrm{~cm}$ dan tinggi $5 \mathrm{~cm}$ berisi medium tanaman yang telah diinfestasi R. solani dengan konsentrasi $1 \%(\mathrm{~b} / \mathrm{b})$. Gejala 
rebah kecambah diamati setelah bibit berumur 21 hari setelah semai.

Penelitian dilakukan di rumah kaca dan tanaman dipelihara dengan menyiram 2 kali sehari pada saat pagi dan sore hari. Peubah yang diamati adalah keparahan penyakit, tinggi dan bobot basah bibit.

Persentase keparahan penyakit dihitung dengan rumus sebagai berikut:

$$
I=\frac{\sum(n \times v)}{Z \times N} \times 100 \%, \text { dengan }
$$

$I$, intensitas keparahan penyakit; $n$, jumlah bibit dari setiap kategori; $Z$, harga numerik dari nilai kategori tertinggi; $N$, jumlah benih yang disemai; $v$, harga numerik dari setiap nilai kategori (0-5) dengan 0 , tidak ada penyakit; 1 , lesio muncul pada leher akar sepanjang $1 \mathrm{~mm}$; 2, lesio cokelat sampai cokelat gelap sepanjang 2-10 mm mengelilingi akar; 3, lesio cokelat gelap sepanjang 10-25 mm dengan miselium mengoloni koleoptil; 4, >25 $\mathrm{mm}$ area akar menjadi hitam dan busuk pada koleoptil; 5, bibit busuk secara menyeluruh atau bibit mati.

Nilai persentase penekanan terhadap keparahan penyakit dihitung menggunakan rumus:

Persentase penekanan $=\frac{\mathrm{K}-\mathrm{P}}{\mathrm{K}} \times 100 \%$, dengan

$\mathrm{K}$, nilai pada perlakuan kontrol; $\mathrm{P}$, nilai pada perlakuan Fusarium nonpatogen

Tinggi tanaman dan bobot basah diamati setelah bibit berumur 21 hari setelah semai. Nilai persentase peningkatan tinggi tanaman dan bobot basah, dihitung berdasarkan rumus: Persentase peningkatan $=\frac{\mathrm{P}-\mathrm{K}}{\mathrm{P}} \times 100 \%$, dengan $\mathrm{K}$, nilai pada kontrol; $\mathrm{P}$, nilai pada perlakuan Fusarium nonpatogen.

Penelitian ini disusun dalam rancangan acak lengkap dengan 16 perlakuan, yang terdiri atas kontrol (tanaman diinokulasi tanpa perlakuan) dan 15 perlakuan isolat Fusarium nonpatogen (isolat F3, F5, F6, F8, F10, F11, F12, F13, F14, F15, F16, F17, F19, F20, dan F21). Masing-masing perlakuan diulang 3 kali dan masing-masing ulangan sebanyak 5 bibit.

Data yang diperoleh dianalisis menggunakan analysis of variance pada taraf uji 5\%. Jika perlakuan berbeda nyata maka antarperlakuan diuji dengan uji Beda Nyata Jujur. Analisis dilakukan menggunakan $R$ Statistical Software (vesion 2.11.1; $R$ Foundation for Statistical Computing Vienna).

\section{HASIL}

\section{Keparahan Penyakit}

Perlakuan Fusarium nonpatogen yang diaplikasikan selama 10 hari saat penyemaian benih memberikan pengaruh nyata dalam menghambat keparahan penyakit rebah kecambah yang disebabkan oleh $R$. solani. Sebagian besar isolat Fusarium nonpatogen yang diuji, kecuali isolat F3, F5, F6, F20, F21 menyebabkan keparahan penyakit yang berbeda nyata dibandingkan dengan perlakuan kontrol (Tabel 1). Isolat-isolat Fusarium nonpatogen yang diuji mampu menekan serangan rebah kecambah dengan persentase penekanan yang bervariasi. Persentase keparahan penyakit pada perlakuan Fusarium nonpatogen (1.78-22.22\%) lebih rendah dibandingkan dengan perlakuan kontrol (54.22\%). Persentase penekanan keparahan penyakit perlakuan Fusarium nonpatogen berkisar 59.02-96.72\%. Sebagian besar isolat Fusarium nonpatogen yang diuji, yaitu isolat F8, F10, F11, F12, F13, F14, F15, F16, F17, dan F13 sangat efektif menekan keparahan penyakit rebah kecambah dengan persentase penekanan $>81.9 \%$, sementara 5 isolat lainnya, yaitu F3, F5, F6, F20, dan F21 menekan serangan rebah kecambah $<68.85 \%$ (Tabel 1).

\section{Tinggi dan Bobot Basah Bibit}

Perlakuan Fusarium nonpatogen pada pembibitan juga memberikan pengaruh nyata terhadap peningkatan tinggi bibit, tetapi tidak berpengaruh nyata pada bobot basah bibit. Perlakuan Fusarium nonpatogen isolat F16, F17, dan F19 berbeda nyata dalam meningkatkan tinggi tanaman dibandingkan dengan kontrol sementara isolat lain tidak. Perlakuan Fusarium nonpatogen meningkatkan tinggi bibit berkisar 40.00-60.98\%, dengan peningkatan tinggi bibit yang terbesar diperoleh melalui perlakuan isolat F19 (Tabel 2). 
Tabel 1 Perlakuan Fusarium nonpatogen terhadap keparahan penyakit rebah kecambah yang disebabkan oleh Rhizoctonia solani

\begin{tabular}{|c|c|c|}
\hline $\begin{array}{l}\text { Isolat } \\
\text { Fusarium } \\
\text { nonpatogen }\end{array}$ & $\begin{array}{c}\text { Keparahan } \\
\text { penyakit } \\
(\%)\end{array}$ & $\begin{array}{c}\text { Penghambatan } \\
(\%)\end{array}$ \\
\hline$\overline{\text { Kontrol }}$ & $54.22 \mathrm{a}^{*}$ & \\
\hline F3 & $17.33 \mathrm{ab}$ & 68.04 \\
\hline F5 & $16.89 \mathrm{ab}$ & 68.85 \\
\hline F6 & $18.22 \mathrm{ab}$ & 66.39 \\
\hline F8 & $2.66 \mathrm{~b}$ & 95.09 \\
\hline F10 & $7.55 \mathrm{~b}$ & 86.08 \\
\hline F11 & $5.77 \mathrm{~b}$ & 89.35 \\
\hline F12 & $7.55 \mathrm{~b}$ & 86.07 \\
\hline F13 & $7.11 \mathrm{~b}$ & 86.89 \\
\hline F14 & $9.78 \mathrm{~b}$ & 81.97 \\
\hline F15 & $4.88 \mathrm{~b}$ & 90.99 \\
\hline F16 & $8.89 \mathrm{~b}$ & 83.61 \\
\hline F17 & $1.78 \mathrm{~b}$ & 96.72 \\
\hline F19 & $9.33 \mathrm{~b}$ & 82.79 \\
\hline F20 & $22.22 \mathrm{ab}$ & 59.02 \\
\hline F21 & $17.78 \mathrm{ab}$ & 67.21 \\
\hline
\end{tabular}

* Angka pada kolom yang sama yang diikuti huruf yang sama tidak berbeda nyata pada taraf 5\%. Data dianalisis setelah ditransformasi arc sin

Tabel 2 Perlakuan Fusarium nonpatogen terhadap peningkatan tinggi bibit yang diinokulasi Rhizoctonia solani

\begin{tabular}{lcc}
\hline $\begin{array}{l}\text { Isolat } \\
\begin{array}{l}\text { Fusarium } \\
\text { nonpatogen }\end{array}\end{array}$ & $\begin{array}{c}\text { Tinggi Tanaman } \\
(\mathrm{cm})\end{array}$ & $\begin{array}{c}\text { Peningkatan } \\
(\%)\end{array}$ \\
\hline Kontrol & $1.19 \mathrm{~b} *$ & \\
F3 & $2.37 \mathrm{ab}$ & 50.14 \\
F5 & $2.36 \mathrm{ab}$ & 49.50 \\
F6 & $2.39 \mathrm{ab}$ & 50.35 \\
F8 & $1.98 \mathrm{ab}$ & 40.00 \\
F10 & $2.07 \mathrm{ab}$ & 42.51 \\
F11 & $2.11 \mathrm{ab}$ & 43.69 \\
F12 & $2.16 \mathrm{ab}$ & 44.99 \\
F13 & $2.26 \mathrm{ab}$ & 47.42 \\
F14 & $2.21 \mathrm{ab}$ & 46.07 \\
F15 & $2.16 \mathrm{ab}$ & 44.99 \\
F16 & $2.63 \mathrm{a}$ & 54.75 \\
F17 & $2.61 \mathrm{a}$ & 54.46 \\
F19 & $3.05 \mathrm{a}$ & 60.98 \\
F20 & $2.36 \mathrm{ab}$ & 49.50 \\
F21 & $2.24 \mathrm{ab}$ & 46.95 \\
*Angka pada kolom yang sama yang diikuti huruf \\
yang sama tidak berbeda nyata pada taraf 5\%. Data \\
dianalisis setelah ditransformasi arc sin
\end{tabular}

Perlakuan Fusarium nonpatogen tidak menyebabkan pengaruh yang berbeda nyata terhadap peningkatan bobot basah bibit. Persentase peningkatan bobot basah bibit berkisar 21.80-66.53\%, dengan 4 isolat meningkatkan bobot basah di atas $61 \%$ yaitu isolat F19 (61.72\%), F17 (64.32\%), F16 (66.33\%), dan F8 (66.63\%) (Tabel 3).

\section{PEMBAHASAN}

Pemanfaatan agens hayati untuk menekan infeksi patogen tular tanah seperti $R$ solani telah dilakukan menggunakan cendawan nonpatogen atau hipovirulen (Sneh 1996; Villajuan-Abgona et al. 1996). Hasil penelitian ini menunjukkan bahwa, perlakuan Fusarium nonpatogen pada masa pembibitan tanaman terung sangat efektif menekan serangan rebah kecambah yang disebabkan oleh $R$. solani. Beberapa penelitian terdahulu, membuktikan bahwa Fusarium nonpatogen sangat efektif dalam menekan serangan layu fusarium pada ubi rambat (Ogawa dan Komada 1984), layu fusarium pada tanaman tomat (Yamaguchi

Tabel 3 Perlakuan Fusarium nonpatogen terhadap peningkatan bobot basah bibit yang diinokulasi Rhizoctonia solani

\begin{tabular}{lcc}
\hline $\begin{array}{l}\text { Isolat } \\
\text { Fusarium } \\
\text { nonpatogen }\end{array}$ & $\begin{array}{c}\text { Bobot basah } \\
\text { (g/tanaman) }\end{array}$ & $\begin{array}{c}\text { Peningkatan } \\
(\%)\end{array}$ \\
\hline Kontrol & 0.55 & \\
F3 & 1.30 & 57.69 \\
F5 & 1.30 & 57.80 \\
F6 & 1.13 & 51.33 \\
F8 & 1.64 & 66.53 \\
F10 & 1.06 & 48.28 \\
F11 & 0.89 & 38.20 \\
F12 & 0.73 & 25.00 \\
F13 & 1.15 & 52.03 \\
F14 & 1.09 & 49.69 \\
F15 & 1.22 & 54.79 \\
F16 & 1.63 & 66.33 \\
F17 & 1.54 & 64.36 \\
F19 & 1.44 & 61.72 \\
F20 & 0.70 & 21.80 \\
F21 & 1.08 & 48.92 \\
\hline
\end{tabular}


et al. 1992), layu fusarium pada semangka (Larkin et al. 1996), dan layu fusarium pada tanaman bayam (Katsube dan Akasaka 1997).

Kemampuan penekanan Fusarium nonpatogen pada penelitian ini, kemungkinan berhubungan dengan mekanisme induksi resistensi yang disebabkan oleh Fusarium nonpatogen. Fuchs et al. (1997) melaporkan bahwa, $F$. oxysporum nonpatogen strain Fo47 sangat efektif mengendalikan penyakit layu fusarium pada tanaman tomat dengan mekanisme induksi resistensi. Inokulasi $F$. oxysporum Fo47 meningkatkan aktivitas kitinase, b-1,3-glukanase, dan b-1,4glukosidase. Penelitian lain yang dilakukan oleh Bolwerk et al. (2005) menunjukkan bahwa, efektivitas pengendalian biologi $F$. axysporum Fo47 terhadap penyakit busuk kaki dan akar pada tanaman tomat yang disebabkan oleh $F$. oxysporum f. sp. radicis-lycopersici melalui mekanisme kompetisi tempat infeksi dan makanan pada permukaan akar dan induksi resisten secara sistemik. Mandeel (2007) menambahkan bahwa efektivitas kompetisi tempat infeksi dan makanan di permukaan akar oleh $F$. oxysporum (C14) terhadap $F$. oxysporum f. sp. cucumerinum pada tanaman mentimun sangat tergantung pada kepadatan inokulum isolat Fusarium nonpatogen tersebut. Mandeel (2006) menambahkan bahwa peningkatan efektivitas Fusarium nonpatogen dalam menekan $F$. oxysporum f. sp. cucumerinum sangat tergantung pada kecepatan perkecambahan spora, respons terhadap eksudat akar, penetrasi akar dan transportasi pasif di batang.

Perlakuan Fusarium nonpatogen pada penelitian ini, disamping sangat efektif menekan keparahan penyakit, juga mampu meningkatkan tinggi bibit dan bobot basah. Muslim et al. (2003) melaporkan bahwa agens pengendali biologi lain yang bersifat nonpatogen ialah Rhizoctonia dua inti nonpatogen yang mempunyai kemampuan yang mirip dengan Fusarium nonpatogen yang diuji pada penelitian ini. Dilaporkan bahwa Rhizoctonia dua inti nonpatogen disamping sangat efektif menekan penyakit layu fusarium pada tomat, juga mampu meningkatkan bobot basah tanaman tomat.

Hasil penelitian ini, menunjukkan bahwa Fusarium nonpatogen sangat potensial untuk dikembangkan sebagai agens hayati dalam mengendalikan penyakit rebah kecambah yang disebabkan oleh $R$. solani. Diharapkan Fusarium nonpatogen dapat mendukung pengendalian penyakit secara terpadu yang ramah lingkungan dan berkelanjutan.

\section{UCAPAN TERIMA KASIH}

Ucapan terima kasih penulis sampaikan kepada Suwandi atas bantuannya dalam analisis data hasil penelitian ini dan kepada Direktorat Pembinaan Penelitian dan Pengabdian Kepada Masyarakat, Direktorat Jenderal Pendidikan Tinggi, Departemen Pendidikan Nasional yang telah membiayai penelitian ini dengan nomor kontrak: 026/ SP2H/PP/DP2M/III/2007.

\section{DAFTAR PUSTAKA}

[BPS] Badan Pusat Statistik Indonesia. 2014. Hortikultura, Statistic Indonesia. www. google.com/?gws_rd=ssl\#q=produksi+ter ung+di+indonesia [diakses 2 Des 2014]

Bolwerk A, Lagopodi AL, Lugtenberg BJJ, Bloemberg GV. 2005. Visualization of interactions between a pathogenic and a beneficial Fusarium strains during biocontrol of tomato foot and root rot. Mol Plant Microb Interac. 18:710-721. DOI: http://dx.doi.org/10.1094/MPMI-18-0710.

Chin CT, Ting FH, Yih CC. 1996. Vegetable disease incited by Rhizoctonia spp., Di dalam: Sneh B, Jabaji-Hare S, Neate SDijst G, editor. Rhizoctonia Species: Taxonomy, Molecular Biology, Ecology, Pathology and Disease Control. Netherlands (NL):Kluwer. hlm. 369-377.

Daunay MC, Janick J. 2007. History and iconography of eggplants. Chronida Hort. 47(3):16-22.

Fuchs J-G, Moenne-Loccoz Y, Defago G. 1997. Nonpathogenic Fusarium oxysporum 
strain Fo47 induces resistance to Fusarium wilt in tomato. Plant Dis. 81:492496. DOI: http://dx.doi.org/10.1094/ PDIS.1997.81.5.492.

Katsube K, Akasaka Y. 1997. Control of fusarium wilt of spinach by transplanting seedlings pretreated with non-pathogenic Fusarium oxysporum. Ann Phytopathol Soc Jpn. 63:389-394 (in Japanese with English summary). DOI: http://dx.doi. org/10.3186/jjphytopath.63.389.

Larkin RP, Hopkins DL, Martin FN. 1996. Suppression of fusarium wilt of watermelon by nonpathogenic Fusarium oxysporum and other microorganisms recovered from a disease-suppressive soil. Phytopathology. 86:812-819. DOI: http:// dx.doi.org/10.1094/Phyto-86-812.

Lu JL. 2011. Insecticide residues in eggplant fruits, soil, and water in the largest eggplantproducing area in the Philippines. Water Air Soil Pollut. 220:413-422. DOI: http:// dx.doi.org/10.1007/s11270-011-0778-9.

Mandeel QA. 2006. Influence of plant root exudates, germ tube orientation and passiveconidia transport on biological control of fusarium wilt by strains of nonpathogenic Fusarium oxysporum. Mycopathologia.161(3):173-182. DOI: http://dx.doi.org/10.1007/s11046-0050211-2.

Mandeel QA. 2007. Modeling competition for infection sites on roots by nonpathogenic strains of Fusarium oxysporum. Mycopathologia. 163: 9-20. DOI: http:// dx.doi.org/10.1007/s11046-006-0080-3.

Muslim A, Horinouchi H, Hyakumachi M.
2003. Biological control of fusarium wilt of tomato with hypovirulent binucleate Rhizoctonia in greenhouse conditions. Mycoscience. 44:77-84. DOI: http:// dx.doi.org/10.1007/S10267-002-0084-X.

Muslim A, Suwandi, Hamidson H. 2006. Evaluasi cendawan rizosper asal lahan rawa lebak sebagai pemacu pertumbuhan tanaman. Agria. 2:26-33.

Ogawa K, Komada H. 1984. Biological control of fusarium wilt of sweet potato by nonpathogenic Fusarium oxysporum. Ann. Phytopath Soc Jpn. 50:1-9. DOI: http:// dx.doi.org/10.3186/jjphytopath.50.1.

Sneh B. 1996. Non pathogenic isolates of Rhizoctonia spp. (np-R) and their role in biological control. Di dalam: Sneh B, Jabaji-Hare S, Neate S, and Dijst G editor. Rhizoctonia species: Taxonomy, Ecology, Pathology and Disease Control. Netherlands (NL): Kluwer. hlm. 473-483. Villajuan-Abgona R, Katsuno N, Kageyama K, Hyakumachi M. 1996. Isolation and identification of hypovirulent Rhizoctonia spp. from soil. Plant Pathol. 45:896-904. DOI: http://dx.doi. org/10.1111/j.1365-3059.1996.tb02900.x.

Yamaguchi K, Sano T, Arita M, Takahashi M. 1992. Biocontrol of fusarium wilt of tomato and verticillium wilt of eggplant by non-pathogenic Fusarium oxysporum MT0062. Ann Phytopathol Soc Jpn. 58:188-194. DOI: http://dx.doi. org/10.3186/jjphytopath.58.188. 